PENELOPE

\title{
DIGITAL EXHIBITION
}

\author{
A Thesis \\ presented to
}

the Faculty of the Graduate School

at the University of Missouri-Columbia

In Partial Fulfillment

of the Requirements for the Degree

Master of Arts

by

POLINA CHELPANOVA

Dr. David J. Schenker, Thesis Supervisor

APRIL 2021 
The undersigned, appointed by the dean of the Graduate School, have examined the thesis entitled

\section{PENELOPE \\ DIGITAL EXHIBITION}

presented by Polina Chelpanova,

a candidate for the degree of master of arts,

and hereby certify that, in their opinion, it is worthy of acceptance.

Professor David Schenker

Professor John McDonald

Professor Sarah Buchanan 


\section{ACKNOWLEDGEMENTS}

I would like to give my sincerest thanks to Pr. Schenker, for letting me explore and pursue this project. My completion of this project could not have been accomplished without the support of the Sager | Braudis Gallery that gave me an opportunity to shadow both their gallery director, Hannah Reeves, as well as assistant director, Rachel Trout, throughout their working day. Because of them, I have received a hands-on experience of working in an art institution and made my first steps in curatorial writing. I would also like to thank David Ligare, a Californiabased contemporary artist, for his generous assistance and permission to use his work that was instrumental to the finalization of this project.

My deepest gratitude to my caring and loving partner, Konrad, for his undying support and his willingness to bounce off ideas all day long. Finally, I would also like to acknowledge my family and friends in Russia who were willing to let me go to the other side of the planet to pursue this degree. 


\section{TABLE OF CONTENTS}

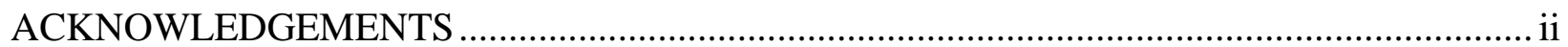

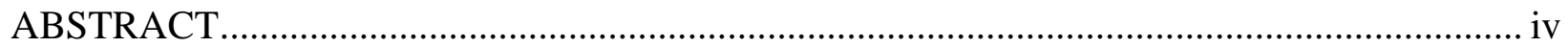

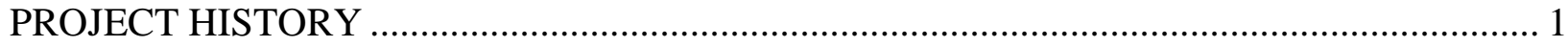

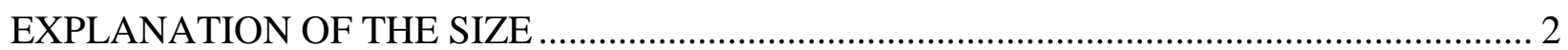

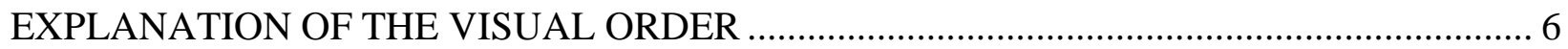

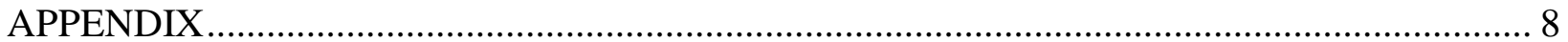

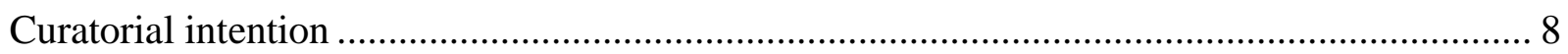

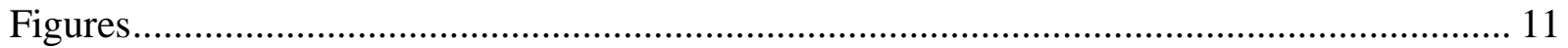

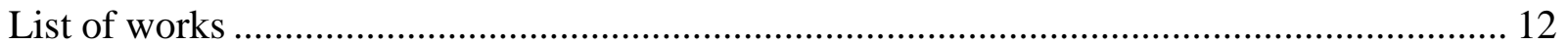

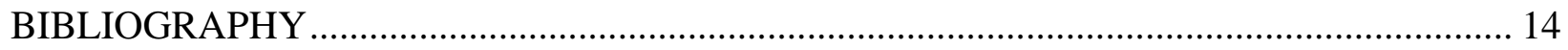




\begin{abstract}
Penelope, the legendary queen of Ithaca, has long been regarded by the public as a faithfully waiting matron and astute wife of Odysseus. This project is designed to present the viewer with different Penelopes as seen through the eyes of the nineteenth and twentieth-century artists. It strives to invite the viewer to participate in a dialogue that has been going since Homeric times, encouraging the visitor to be inquisitive about the actual nature of a well-known character.
\end{abstract}




\section{PROJECT HISTORY}

The idea of creating an exhibition as my thesis project came to me as soon as I arrived to Columbia. Having consulted with my academic advisor at that time, Dr. Gurd, it seemed to be possible to collaborate with the Museum of Art and Archaeology at the University of Missouri and create an exhibition on Roman Imperial artifacts with a focus on objects coming from provinces. However, after several fruitless attempts to contact both Pr. Benton Kidd and Pr. Kristin Schwain, it became clear that the alleged collaboration between the departments, as well as the Museum Studies graduate certificate, simply did not exist.

Later, having attended the digital humanities workshop at the University of Indiana Bloomington during the spring symposium "Past Forward: New Ways of Seeing Old Things" in March 2020, I came up with an idea to create a website-companion for the Homeric epic cycle, using XML formatting. I was set on an idea to explore the educational possibilities of digital humanities by creating a hub of information that concerned the epic poem Iliad. The original plan was to combine both literary commentaries and the recent findings of the archaeological studies of the Bronze and Early Iron Age Greece so that the students would have a better understanding of both literary and material sides of the epic. However, after several discussions with my academic advisor, Pr. Schenker, I came to the conclusion that I would not have the tools to make an undertaking like this a reality.

Finally, the project took its current shape over the summer, when I turned back to my original idea for the thesis project, an exhibition. I saw that the Museum of Art and Archaeology at the University of Missouri had published several digital exhibitions on their Facebook page. Considering that the pandemic started a couple of months before, I thought that creating a digital exhibition would be a good way to approach my thesis in such uncertain times. 
Having heard in April from a recent graduate that they got a credit internship from the University of Missouri's museum, I decided to reach out to them and ask about a possible internship, presented on their website as docent training. By working there, I was hoping to learn practical skills of museum exhibition-making as well as to get an insider's perspective on the internal museum processes. Due to the same pandemic, I had to wait for more information from the contact in the museum, Dr. Callaway, on docent training, as no one was sure that the museum or the university would be opened in the fall. In mid-August, she told me that the training was not an internship and that it entailed a three-year commitment that I would not have been able to fulfill, due to my contract with Fulbright.

My initial proposition for the exhibition was to create an exhibit that would investigate different themes in the Trojan War cycle, such as PTSD in Trojan War, Helen of Troy, Troy in popular culture, etc. After bouncing ideas with the advisor, we came to the conclusion that this project needed to be scaled down. This led me first to choose just one theme - Women in the Trojan War and then to just one character - Penelope, the queen of Ithaca.

You can access the online exhibit through this link.

\section{EXPLANATION OF THE SIZE}

From the very beginning, the number of artworks in the exhibit was fluctuating between fifteen and twenty different artworks. Having been both to the huge museum institutions, as well as to the smallest galleries with just one room, I have felt that it was easier for me to appreciate the work of art and study it when there were fewer artworks at the exhibit. And indeed, 
contemporary art institutions are slowly but surely changing their practices and shifting their focus from a traditional object display. ${ }^{1}$

However, the decision was influenced also by several issues that I have encountered during the preparation of the materials and exhibition. The biggest problem of all was the inability to find the reproduction in a good enough quality or the information about the artist's piece, such as provenance, the date of creation, etc. One of these unfortunate artworks was a fascinating painting Penélope Corre ao Encontro de Ulisses created by a brilliant Portuguese surrealist artist Mario Cesariny. Using both conventional google searches and specialized contemporary art and auction databases, I was not able to find further information about the piece or better resolution of the artwork. Therefore, some of the showpieces previously mentioned in the preliminary list of works never made it to the final product.

A similar issue occurred at a later stage of the project development when I was trying to define the copywrite restrictions for the pieces that I was left with at that point. Unfortunately, I failed to find explicit information about the fair use licensing and consent of the owner of an artwork that I wanted to use for my exhibit, therefore, I have decided not to use the pieces with vague copywrite restrictions in my work to avoid the copywrite infringement.

Moreover, budgeting issues were also crucial in my choice of the number of artworks. The service that I was using to build my website allows only a very limited number of pages in its free version. Thus, I was trying to fill all the pages I could without a need to pay for it, having both pages for the curatorial intention as well as the paintings.

\footnotetext{
${ }^{1}$ McKenna-Cress and Kamien, Creating Exhibitions: Collaboration in the Planning, Development, and Design of Innovative Experiences, 74.
} 
Most of my education about exhibition-making was based on the pictures of the actual materials that the art institutions put out on their websites and in their exhibition halls, as well as the physical visiting of as many museums in America as the opportunity allowed. Among them were Dixon Gallery and Brooks Museum of Art in Memphis, TN, our local Museum of Art and Archaeology affiliated with the University of Missouri, as well as Sager | Braudis Gallery in the North Village Art District of Columbia, MO.

The last one was especially crucial in my understanding of exhibition design, what kind of research is made in the art institutions, as well as the process of elimination and inclusion of different artists in the show. There, I was also encouraged to try myself in curatorial and promotional writing for the gallery, for example, you might have heard a radio spot on a local NPR station about Alice Neel or Elaine de Kooning that I wrote this April. Especially this month, I was closely working with the gallery director, Hanna Reeves, who spent a lot of time with me discussing the goals that the exhibition has in general, the nuances of the art market and the borrowing of the artworks, as well as gave me advice on my writing and how to shift from a dry dense academic style to more relaxed and engaging style used in PR and curatorial materials. I am also grateful to Hannah that she allowed me to go through the catalogs for the past exhibitions of the galleries to analyze them and apply these techniques to my own work.

I was very lucky to be able to be at several discussions of the collection as well as conversations about the choice of the artists represented in future exhibits. Although I cannot release the details of these deliberations, due to my non-disclosure agreement with the gallery, I will note several tendencies that I have noticed while listening in. First of all, the gallery has always been striving for the greater diversity of the artists they represent, the trend that I was trying to reflect in my exhibition by showing a greater geographical diversity of the painters, as 
well as showcasing the works of the craftsmen that are usually overlooked by the mainstream narrative of art history, especially focused on Britain and France at the beginning of the twentieth century and in its latter half exclusively on America. Unfortunately, I could not have achieved a gender-balanced exhibition, mostly because the art scene of the later nineteenth and early twentieth centuries were dominated by men, and because most women at the first half of the twentieth century belonged to the avant-garde movements that generally opposed and refused to use the themes of the "old" art, turning to the depiction of the everyday life of an average man and striving to capture the quickly advancing technological progress. ${ }^{2}$

The second observation that I have made during my time at the Sager | Braudis Gallery, is that the directors are, first and foremost, concerned with the quality of the art that they represent, rather than its quantity. Overall, the idea of the overwhelming number of works showcased on the walls, or the multitude of objects on the display comes from the nineteenth century. On the one hand, the first official art institutions at that time were great salons, where various artists were represented. Following the fashion of that age, as well as the necessity of exhibiting multiple artists at the same show, the organizers crammed dozens of pieces on the same wall (fig. 1). On the other hand, the "curators" themselves are historically connected to the custodianship of libraries and archives, keeping and researching collections. ${ }^{3}$ However, today the curatorship outgrew these frames and, in many ways, moved on from its historical function into public relationship, education, and promotion. ${ }^{4}$ Therefore, I believe that it is best to concentrate on few pieces in my exhibit, so that the viewer would not be buried by the avalanche of works of art, but

\footnotetext{
2 Joselit et al., Art since 1900 : Modernism, Antimodernism, Postmodernism.

${ }^{3}$ McKenna-Cress and Kamien, Creating Exhibitions: Collaboration in the Planning, Development, and Design of Innovative Experiences, 24.

${ }^{4}$ Jeffries and Groves, "Hans Ulrich Obrist: The Art of Curation."
} 
rather take his time to think about these pieces carefully, appreciating them without rushing oneself.

\section{EXPLANATION OF THE VISUAL ORDER}

My idea for the visual order can be best described by the word cycle. The composition of the exhibition on the landing page consists of nine small square images that constitute the bigger square. However, one could see the outer part of this square as a continuous never-ending line, not unlike the geometrical figure circle. This circle is the Homeric cycle, the cycle of life in general, as well as particularly the cycle of Penelope's life. Further, I would like to talk especially about the former and the latter interpretations of the circular visual order.

Contrary to the public view, the Homeric cycle does not fit in all the myths about Penelope. The Odyssey, for example, describes only the time when Odysseus was trying to get home and how Penelope was waiting for him, deceiving the suitors and raising her son. That is why the scenes that belong to the epic poem Odyssey, which is an integral part of the Homeric cycle, are put into an outer rim of the square, connected by the invisible line going through all of them. As for the middle of this circle, in this case, it harbors one piece that was inspired by an event from Penelope's life but was not explicitly mentioned in the Homeric epic. However, it was most probably known to the Ancient Greek listeners of this timeless story. The version of this myth we know in our days comes from the Description of Greece by Pausanias. In the text, the geographer relates how Penelope left Lacedaemon, having covered her face with a veil in reply to the question of her father, Icarius, whether she wants to stay in Sparta or go to Ithaca 
with her new husband. ${ }^{5}$ Therefore, this particular piece stands apart by being placed in the center of the circle.

The other reason for this visual order, as well as the click-through order, is that I wanted to show a limbo state of Penelope's life through it. The modern audience mostly knows Penelope as the modest and intelligent wife who was defending herself from the attacks of the suitors, waiting when her husband comes back from war. This way, Penelope exists only from the moment when Odysseus leaves for war and ends with his return. In my opinion, this confines her into a never-ending cycle of waiting for Odysseus' return without ever letting her have her own story. Therefore, when a visitor would go into the gallery section of the exhibit, they themselves will be trapped into the same limbo state without a real beginning or ending.

To increase this effect, I resorted to only one navigation button "next artist." On the one hand, it creates a certain level of discomfort that usually goes hand-in-hand with a limbo state, on the other, it reflects the nature of our very lives that only goes forward, speeding by us. I believe this is especially noticeable because the pieces are not sorted in the chronological order of Penelope's life cycle. As a matter of fact, it starts at the end of the story related in the Odyssey. Then, we see three pictures that reflect her anxieties and her attempts to trick the suitors. Although, Auburtin's piece disrupts this motion, bringing us back to the beginning of the queen's life in a flashback of sorts. However, it soon goes back to the times of uncertainty when she had to weave and destroy her work to keep her suitors at bay and herself in power as a sole-ruling basileia. ${ }^{6}$ When finally, a visitor comes back to the end of the story with Čikoš Sesija’s piece but then the cycle begins again and could rotate infinitely.

\footnotetext{
${ }^{5}$ Pausanias, Graeciae Descriptio, 3.20.11.

${ }^{6}$ Roller, Cleopatra's Daughter: And Other Royal Women of the Augustan Era, 8-9.
} 


\section{APPENDIX}

\section{Curatorial intention}

The current exhibition encompasses works of both 19th and 20th-century masters, the rebels against classicism and academism. Witnesses of the ushering new, complicated but hopeful era, the painters boldly set out in the search of new art, contesting the mores and expectations of that time. Despite their distaste of the traditional post-Renaissance style of painting, these rebels were still drawn by the themes and motives, the academic art environment recycled for centuries. A huge portion of these was taken from ancient mythology and history, but now the well-known characters were starting to become real chameleons, reflecting the realia of the period and the artists' own worldview.

For many of these creators, Penelope ceased to be simply a passively waiting wife but became a way to show the strategic intelligence and resourcefulness of a woman, independent from her husband. Therefore, going from one piece to another in this exhibition you will be able to see different Penelopes, some of them would be more stereotypical, others less.

However, to fully appreciate their work we should first try to identify the original Penelope and ask ourselves who was she and what was her personality. She was, in fact, the first woman who was called basilea in Greek literature. The title reflected her decades-long status as de-facto independent ruler of Ithaca and the fact that she was austerely and, one could say, stubbornly refusing to choose a partner. Irresponsive to her family and suitors' pressure to choose a co-ruler, she shows time and again that her seeming passivity was in reality a source of strength. Over the course of these years, she comes up with different stratagems, weaving the funerary shroud of her father-in-law, which is the most represented of her ruses in the exhibition. 
A very telling characterization of the Queen of Ithaca actually comes from the shadow of dead Agamemnon in Hades, who compares his own wife, Clytemnestra, to Penelope saying that

her fame will live

forever, and the deathless gods will make

a poem to delight all those on earth

about intelligent Penelope.

(Odyssey, 24. 197-200, Emily Wilson's translation)

In accordance with the praise, this exhibition seeks to once again highlight the shifty and complicated nature of Penelope through no less complicated and dissimilar works of art. This not only stylistic, but more importantly, psychic variety, explored by artists throughout centuries, allows us to find a new way of looking at an already familiar character, as well as human beings in general.

\section{Concluding reflection}

This exhibition has started with an open-ended question: who was Penelope? Was she merely a modest wife who was waiting for her husband, the way that modern society thinks of her? Or was she more than that? Each of us, with our personal experience, struggles, and ideals, sees in Penelope something different, something unique that manifests itself both in literature and visual arts.

Portraiture, one of the most versatile genres of visual arts, triggers a subconscious process of finding out the character of a person through the corners of their eyes, the turn of their lips, or their pose and body language. Contrary to the famous saying, we develop and nurture the skill of reading people's expressions throughout our lives, usually making our first impressions about the person by their appearance. Therefore, the patient study of the portrait allows a viewer to go 
beyond just the quick surface evaluation, giving us an opportunity to deepen our understanding of the character and carefully consider their motivations.

The aim of this exhibition was to free Penelope from the constraints of the basic archetypes and stereotypes of a "dangerous woman" or a "respectable matron," and allow the viewer to engage with the whole spectrum of Penelopes with their natural complexities and controversies. I hope that the project would encourage the viewer to embark on their own journey of finding Penelope, contributing to the timeless dialogue that goes on for millennia. 


\section{Figures}

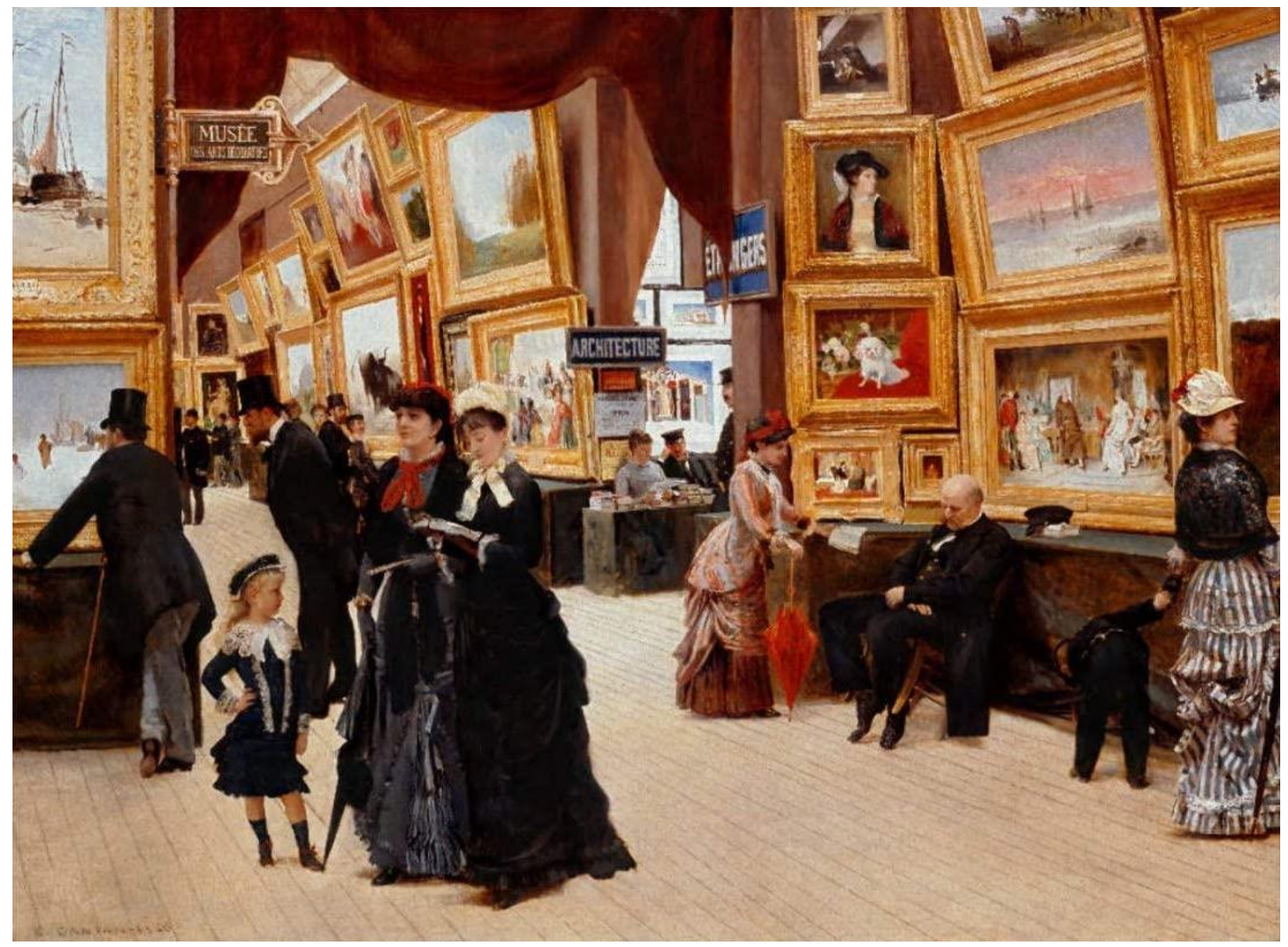

(Fig. 1) Édouard Joseph Dantan — Un coin du Salon en 1880. Created in 1880, currently is in private collection. (Retrieved from www.commons. wikipedia.org). The image is in public domain due to the expiration of the copyright in the country of origin, other countries and areas where the copyright term is the author's life plus 100 years or fewer. 
List of works

Title

Penelope

Penelope

Penelope

Penelope Unraveling Her Work at Night

Departure of Ulysses and Penelope for Ithaca

Penelope and the Suitors

Penelope

Odysseus and Penelope Reunited

Penelope
Artist's name

Bela Čikoš Sesija

Benton Murdoch Spruance

David Ligare

Dora Wheeler

Jean-Francis Auburtin

John William Waterhouse

Max Klinger

Romare Howard Bearden

Tano Festa
Date

1894

1956

1980

1886

1892

1912

1896

1977

1986 


\begin{abstract}
Penelope, the legendary queen of Ithaca, has long been regarded by the public as a faithfully waiting matron and astute wife of Odysseus. This project is designed to present the viewer with different Penelopes as seen through the eyes of the nineteenth and twentieth-century artists. It strives to invite the viewer to participate in a dialogue that has been going since Homeric times, encouraging the visitor to be inquisitive about the actual nature of a well-known character.
\end{abstract}




\section{BIBLIOGRAPHY}

Arnold, Dana. Art History : A Very Short Introduction. Oxford University Press, 2004.

Atwood, M. The Penelopiad. Myths (Canongate Publishing). Canongate, 2005.

Cavallaro, D. J.W. Waterhouse and the Magic of Color. McFarland, Incorporated, Publishers, 2017.

David Cottington. Modern Art: A Very Short Introduction. Very Short Introductions. Oxford [England]: OUP Oxford, 2005.

Detienne, M. Comparative Anthropology of Ancient Greece. Center for Hellenic Studies Colloquia Series. Center for Hellenic Studies, 2009.

Fine, R., R.F. Looney, B. Spruance, and Free Library of Philadelphia. The Prints of Benton Murdoch Spruance: A Catalogue Raisonné. Free Library of Philadelphia by the University of Pennsylvania Press, 1986.

Hardwick, Lorna, and Christopher Stray. A Companion to Classical Receptions. Blackwell Companions to the Ancient World. Literature and Culture. Blackwell, 2008.

Jean-Francis Auburtin (1866-1930). “Ciel et Mer”. Galerie Doyen, 2014. https://issuu.com/idinteractive/docs/catalogue_auburtin_pour_le_site_6da2531d8918ea.

Jeffries, Stuart, and Nancy Groves. "Hans Ulrich Obrist: The Art of Curation.” Guardian. March 23, 2014. https://www.theguardian.com/artanddesign/2014/mar/23/hans-ulrich-obrist-artcurator.

Joselit, David, B. H. D. Buchloh, Yve-Alain Bois, Rosalind E. Krauss, and Hal Foster. Art since 1900 : Modernism, Antimodernism, Postmodernism. Third edition. Thames \& Hudson, 2016.

Keith, Alison, and Jacqueline Fabre-Serris. Women and War in Antiquity. Baltimore: Johns Hopkins University Press, 2015.

McEwen, John. “My Favourite Painting: Robert Adam.” Country Life, July 20, 2020.

McKenna-Cress, P., and J. Kamien. Creating Exhibitions: Collaboration in the Planning, Development, and Design of Innovative Experiences. Wiley, 2013. 
Neils, J. Women in the Ancient World. British Museum Press, 2011.

O’Meally, R.G., R. Bearden, B. Moore, and D. C. Moore Gallery. Romare Bearden: A Black Odyssey. DC Moore Gallery, 2007.

Roller, D.W. Cleopatra's Daughter: And Other Royal Women of the Augustan Era. Women in Antiquity. Oxford University Press, 2018.

Stallabrass, Julian. Contemporary Art: A Very Short Introduction. Very Short Introductions. Oxford: OUP Oxford, 2006.

Tatum, James. "A Real Short Introduction to Classical Reception Theory." Arion: A Journal of Humanities and the Classics 22, no. 2 (2014): 75.

Vuković, Radovan. Za Psihom, Sliko! Zagreb: Umjetnički paviljon, 2012.

Wilson, E. The Odyssey. W. W. Norton, 2017.

Zlamalik, Vinko. "Bela Čikoš Sesija: Začetnik Simbolizma u Hrvatskoj." Sveučilište u Zagrebu, 1983. 